\title{
STRATIGRAPHIC FRAMEWORK FOR GEOLOGIC AND GEOHYDROLOGIC STUDIE S OF THE SUBSURFACE CRETACEOUS SECTION NEAR CHARLESTON, SOUTH CAROIINA
}

\author{
By Bruce G. Campbell and Gregory S. Gohn
}

1994

\section{INTRODUCTION}

This report illustrates the distribution of 11 formations that constitute the subsurface Cretaceous section near Charleston, South Carolina. Data from 14 drill holes are used to construct four geologic sections in southern Dorchester County and the Charleston-Mt. Pleasant area of central Charleston County (figs. 1, 2). Stratigraphic and lithologic information for the Cretaceous formations are discussed in the first part of this pamphlet along with brief descriptions of their ages and depositional paleoenvironments. Particular emphasis is placed on establishing criteria for recognizing the Cretaceous formations in cores and cuttings and on geophysical logs. The geohydrology of the Cretaceous section is discussed in the second part of this pamphlet. This latter section contains a discussion of the physical characteristics of Cretaceous sands as they relate to water-bearing properties as well as a discussion of the principal Cretaceous aquifer in the Charleston area.

The drill holes used to construct the geologic sections consist of one continuously cored stratigraphic test hole, USGS-Clubhouse Crossroads \#1 (fig. 1; DOR-37), and 13 municipal or private water wells. Geophysical logs were available for all of these drill holes, and cuttings were studied from the deepest water well, well CHN-635 located on Sullivans Island (fig. 2). Drillers logs were available for some of the water wells. Selected data from Stephenson's (1914) report on an additional well in Charleston city (CHN-14, fig. 2), and hydrologic data from an additional well in Mt. Pleasant (CHN-167, fig. 2), also are included.

The geophysical logs used in this report are generalized digital versions of the original logs. Data curves on the original logs were read at 2-foot intervals to produce the digital files used to display the logs on the geologic sections. This procedure tends to omit some thin spikes, to clip some high-amplitude spikes, and to produce generally smoother curves than are present on the original logs. However, these digital logs remain adequate for studying the 50 - to 400 -foot-thick units described in this report. Several combinations of gamma-ray and (or) electric logs (spontaneous potential with short-normal, single-point, or lateral resistivity) are used on the sections. The electric logs for drill holes $\mathrm{CHN}-172$ and $\mathrm{CHN}$ 173 have "reversed" spontaneous potential curves on which positive deflections (relative to the curve position opposite clay intervals) occur opposite freshwater sands rather than the conventional negative deflections. The datum for the geologic sections is the Cretaceous-Tertiary boundary; drill-hole depths are in feet. Conversion factors follow References Cited. Figures 1, 2, and 3 are on the sheet containing sections $A-A^{\prime}$ and $B-B^{\prime}$, whereas figures 4 and 5 are in this pamphlet.

\section{Acknowledgments}

We are indebted to Mr. Leo Truesdell of the Water Department of the town of Sullivans Island for allowing us to examine the drill cuttings from water well $\mathrm{CHN}-635$. We also thank Steven Schindler (USGS) for his help in generating the digital files and printouts for the sections and Kevin Conlon (USGS) for preparing splits of the CHN-635 cuttings. Reviews by W. Fred Falls, Francis Chapelle, and especially David Prowell (all USGS) substantially improved the manuscript.

\section{STRATIGRAPHY}

\section{STRATIGRAPHIC FRAMEWORK}

Several regional stratigraphic or geohydrologic sections published during the past 15 years include some of the drill holes used in this study. These reports show the distribution of mostly informal lithostratigraphic, chronostratigraphic, and (or) geohydrologic units in widely spaced drill holes spread across the South Carolina Coastal Plain (Gohn and others, 1978; Brown and others, 1979; Colquhoun and others, 1983; Aucott and others, 1987). In contrast, this report focuses on the distribution of formally defined lithologic units in a relatively small area with comparatively dense drill-hole coverage.

The Cretaceous stratigraphy used in this report was established by Gohn (1992), and summarized by Gohn and Campbell (1992), for the USGS-Clubhouse Crossroads \#1 stratigrashic corehole (fig. 1; DOR-37). Gohn (1992) substantially modified the four formations originally recognized in preliminary studies of the core by Gohn and others (1977) and Hazel and others (1977) (see fig. 3) to conform with the present concepts of these units in their outcrop type sections. Of these four units, the Cape Fear, Middendorf, and Peedee Formations were retained with corrections to their identification in the subsurface. The Black Creek Formation was raised to group status (fig. 3), following the use of a Black Creek Group in the Cretaceous outcrop belt of the Carolinas by Owens (1989), and now consists of four formations: the Cane Acre and Coachman Formations, which were defined in the subsurface (Gohn, 1992), and the Bladen and Donoho Cree', Formations, which were defined in the outcrop belt (Owens, 1089; Sohl and Owens, 1991). Four new subsurface units, the Beech Hill, Clubhouse, Shepherd Grove, and Caddin Formations, also were defined (Gohn, 1992). Informal Cretaceous units previously recognized in the Clubhouse Crossroads section by Gohn and others (1978) and Brown and others (1979) are correlated to the present stratigraphy on figure 3 . 


\section{STRATIGRAPHIC UNITS}

\section{Beech Hill Formation}

The oldest Cretaceous unit in the study area is the Beech Hill Formation, whose type section is from 2,464 to $2,417 \mathrm{ft}$ in the USGS-Clubhouse Crossroads \#1 core (fig. 3; DOR-37, section $\left.A-A^{\prime}\right)$ (Gohn, 1992). There, the lower contact of the Cretaceous section is sharp between a basal feldspathic clayey sand of the Beech Hill and underlying, strongly weathered, early Mesozoic basalt. The 47-foot-thick Beech Hill type section consists of an 11-foot-thick basal section of yellow-, brown-, and white-mottled, noncalcareous, poorly sorted, massive clayey sand that contains altered basalt pebbles. Above 2,453 ft, the unit consists of brownish-gray and greenish-gray, hard, noncalcareous, unfossiliferous clay. A bed of noncalcareous, yellowish-gray, muddy, feldspathic, fine to coarse sand occurs at 2,437 to 2,435 ft.

The assigned age of the unfossiliferous Beech Hill Formation is derived primarily from its stratigraphic position. Gohn (1992) assigned a Cenomanian(?) age to the Beech Hill on the basis of fossils in the overlying Cenomanian(?) and Turonian Clubhouse Formation. Gohn (1992) also inferred fluvial to perhaps colluvial paleoenvironments for deposition of the Beech Hill sediments.

The USGS-Clubhouse Crossroads \#1 corehole is the only drill hole in the study area that reaches the Beech Hill Formation. Although water well $\mathrm{CHN}-635$ (sections $A-A^{\prime}, D-D^{\prime}$ ) was drilled to a similar depth, it is located obliquely downdip from Clubhouse Crossroads and only reached the Clubhouse Formation above the Beech Hill.

The principal criteria for recognizing the Beech Hill Formation in the Charleston area are its position at the base of the Coastal Plain section immediately above pre-Cretaceous rocks and its strong lithologic contrast with the overlying Clubhouse Formation (see description below). The gamma-ray and spontaneous potential logs accurately depict the basal sand and the upper clayey section in the Beech Hill Formation at Clubhouse Crossroads (section $A-A^{\prime}$, DOR-37).

\section{Clubhouse Formation}

The type section of the Clubhouse Formation is the interval from 2,417 to 2,338 $\mathrm{ft}$ in the USGS-Clubhouse Crossroads \#1 core (section $A-A^{\prime}$, DOR-37) (Gohn, 1992). This 79-foot-thick section consists primarily of dark-gray to brownish-gray silty clays that alternate on a scale of inches to tenths of inches with moderately well-sorted, light-gray to pale- olive silts and very fine to fine sands. In addition, 4-foot-thick beds of gray, medium sand occur at the base $(2,417$ to $2,413 \mathrm{ft})$ and at 2,368 to $2,364 \mathrm{ft}$. Abundant sand-sized detrital mica and lignitic plant material are common in both lithologies. Flaser and lenticular bedding are characteristic of the unit, as are common small burrows and larger vertical U-shaped burrows. Mollusk fragments, dinoflagellates, and calcareous micro- and nannofossils are locally sparse to common throughout most of the section (Hazel and others, 1977; Valentine, 1982, 1984).

Strong lithologic contrasts are apparent between the Clubhouse Formation and the underlying Beech Hill Formation although the actual contact interval was not recovered in the Clubhouse Crossroads core. However, cores recovered from within one foot of the contact in both units illustrate the differences between the typically massive, noncalcareous, dominantly brown and yellow sediments of the Beech Hill Formation and the typically thin- bedded, burrowed, fossiliferous, gray sediments of the Clubhouse Formation.
Gohn (1992) assigned a Cenomanian(?) and Turonian age to the Clubhouse Formation in its type section on the basis of palynomorphs and calcareous nannofossils discussed by Hazel and others (1977) and Valentine $(1982,1984)$. The association of common burrows and planktic microfossils with abundant detrital lignite and flaser, and lenticular bedding indicates a shallowsubtidal to peritidal paleoenvironment of deposition (Gohn, 1992).

DOR-37 and CHN-635 are the only drill holes that are deep enough to penetrate the Clubhouse Formation in the study area (section $A-A^{\prime}$ ); only a partial thickness of $136 \mathrm{ft}$ was recorded in the $\mathrm{CHN}-635$ hole as it did not reach the bottom of the formation. Although its full thickness was not penetrated in $\mathrm{CHN}-635$, substantial thickening of the Clubhouse Formation from west (79 $\mathrm{ft}$ ) to east (greater than $136 \mathrm{ft}$ ) is apparent along section $A-A^{\prime}$.

Samples of cuttings from below $2,400 \mathrm{ft}$ in the $\mathrm{CHN}-635$ drill hole contain abundant chips of shelly and (or) lignitic, mediumgray clay. The highest occurrence of these gray clay chips in the sample from 2,400 to $2,412 \mathrm{ft}$ was used, in conjunction with the geophysical logs, to establish the top of the Clubhouse Formation at $2,400 \mathrm{ft}$ in this well (sections $A-A^{\prime}, D-D^{\prime}$ ). Similarly, the highest occurrence of abundant, gray clay and clayey silt below a thick section of oxidized clays and sands in the overlying Cape Fear Formation (see below) should be a principal criterion for recognizing the top of the Clubhouse Formation in cuttings from other deep water wells. The $\mathrm{CHN}-635$ geophysical logs indicate that several 2 to 6-foot-thick sands are present in the Clubhouse Formation; these sands resemble the two similarly thick sands in the Clubhouse Crossroads core.

\section{Cape Fear Formation}

The original definition of the Cape Fear Formation in the USGSClubhouse Crossroads \#1 core by Gohn and others (1977) was substantially modified by Gohn (1992) to more closely conform with the concept of that unit in its outcrop type section (Heron and others, 1968; Sohl and Owens, 1991). At Clubhouse Crossroads, and in many other parts of the South Carolina Coastal Plain (for examples, see Prowell and others, 1985; Reid and others, 1986; Fallaw and others, 1990), the Cape Fear Formation primarily consists of numerous 10- to 30-foot-thick, fining-upward, sandclay cycles. Above a sharp erosional contact at its base, each cycle consists of yellowish-gray, feldspathic, medium-to-very coarse sand or gravelly medium-to-very coarse sand that grades upward into red, yellow, and brown, sandy and (or) silty clay. In the Clubhouse Crossroads \#1 core, the contact of the Cape Fear Formation with the underlying Clubhouse Formation at $2,338 \mathrm{ft}$ is sharp between a basal, hard, red-brown clay of the Cape Fear and thinly interbedded pale-olive, micaceous fine sands and grayisholive, lignitic clays at the top of the Clubhouse.

The Cape Fear Formation is largely unfossiliferous; however, sparse planktic fossils found in a few samples from its upper part, as well as fossils in the overlying and underlying units, place constraints on the possible age of the Cape Fear (Hazel and others, 1977; Valentine, 1982, 1984). Gohn (1992) reviewed the available data and assigned a late Turonian(?), Coniacian(?), and Santonian age to the Cape Fear Formation in the USGSClubhouse Crossroads \#1 core.

The fining-upward sand-clay cycles in the Cape Fear suggest channel and overbank sedimentation by a mixed-load, meandering channel system. The presence of marine microfossils at least locally in the unit suggest that these channels may have been part of a large estuarine or tidal-delta system rather than a fluvial system. 
The Cape Fear Formation is the thickest unit $(477 \mathrm{ft})$ in the USGS- Clubhouse Crossroads \#1 core (figure 3 ; section $A-A^{\prime}$ ). Elsewhere, the full thickness of the Cape Fear was penetrated only in the CHN-635 water well (sections $A-A^{\prime}, D-D^{\prime}$ ) where $375 \mathrm{ft}$ of section is present. Nine other wells penetrate $100-$ to 300 -footthick partial sections of the Cape Fear Formation. Thinning of the Cape Fear Formation from west to east along section $A-A^{\prime}$ (DOR-37 to CHN-635) might be related to west-to-east thickening of the overlying Middendorf Formation (see below).

The Cape Fear Formation is the most distinctive unit in the study area. The thick Cape Fear section of strongly oxidized, sparingly calcareous clays and coarse, feldspathic sands contrasts with sections of grayish, lignitic, locally strongly calcareous sediments in the underlying and overlying formations. The top of the Cape Fear section is typically apparent in water-well cuttings as the oxidized clays tend to strongly tint drilling muds, imparting a reddish color to Cape Fear samples. For example, the highest mention of red, pink, or white clays on water-well drillers logs from the study area is invariably from the upper $50 \mathrm{ft}$ of the Cape Fear section, as determined independently from geophysical logs (see sections).

The Cape Fear Formation is readily recognized on electric logs by the distinctively low resistivities of its sands. These low values probably result from a combination of factors, which may include decreased porosity due to high secondary matrix contents and the presence of relatively saline groundwater. Very high values seen locally on gamma logs for the Cape Fear section possibly represent concentrations of radiogenic elements in heavy-mineral sands or at permeability boundaries.

\section{Middendorf Formation}

Gohn (1992) substantially modified the concept of the Middendorf Formation used by Gohn and others (1977) for the Clubhouse Crossroads \#1 core (fig. 3). The revised Miaddendorf section in the core $(1,861$ to $1,754 \mathrm{ft})$ consists of moderately thick, medium- gray, moderately well sorted, feldspathic, coarse to very coarse to gravely sands in the lower part of the unit and a distinctive macrofossiliferous, fine-to-coarse sand at the top. Finegrained sections between and above the lower sands consist of dark-gray. lignitic, micaceous, silty clays that are interbedded with light- gray, micaceous, calcareous silts and very fine sands at scales of inches to tenths of inches.

The lower contact of the Middendorf Formation with the Cape Fear Formation in the Clubhouse Crossroads section is marked by a pronounced lithologic change. Although the actual Cape FearMiddendorf contact was not recovered, the characteristically gray, lignitic, and locally fossiliferous sediments of the Middendorf contrast strongly with the characteristically oxidized sands and clays of the Cape Fear.

The coarse sands in the lower part of the Middendorf are sparingly fossiliferous to unfossiliferous, but the remainder of the unit contains locally sparse to common calcareous microfossils, fragmented mollusks, and palynomorphs. In particular, the sand at the top of the formation is characterized in the Clubhouse Crossroads core (Hazel and others, 1977) by common to abundant specimens of the small oyster Ostrea cretacea. Stephenson (1914) also identified $O$. cretacea in cuttings from the 1,812- to $1,800-\mathrm{ft}$ sample (and lower) in the CHN-14 water well (fig. 1) as well as a questionable juvenile specimen in the 1,730- to 1,725 - $\mathrm{ft}$ sample from the same well. Stephenson's $(1914 ;$ p. 77,82$)$ certain identification of $O$. cretacea in "loose coarse quartz sand" at 1,812 to $1,800 \mathrm{ft}$ in $\mathrm{CHN}-14$ is consistent with the placement of the top of the Middendorf just below $1,800 \mathrm{ft}$ in the nearby $\mathrm{CHN}-178$ well (fig. 1; section $A-A^{\prime}$ ). Gohn (1992) assigned a Santonian age to the Middendorf Formation at Clubhouse Crossroads on the basis of paleontologic data in Hazel and others (1977), Hattner and Wise (1980), and Valentine (1982, 1984).

Gohn (1992) inferred marginal-marine paleoenvironments for deposition of the Middendorf sediments. The transition within the Middendorf Formation from fluvial-to-estuarine chennel sands at its base to the shallow-marine oyster-rich sand at the top is seen in all the studied wells and indicates sedimentation during a relative rise in sea level.

All of the studied drill holes penetrated the comple ${ }^{+o}$. Middendorf section except $\mathrm{CHN}-601$ and $\mathrm{CHN}-219$ (section $D-D^{\prime}$ ), which penetrated nearly complete sections, and $\mathrm{CHN}-172$ (section $A-A^{\prime}$ ), which probably penetrated about half the unit. The Middendorf Formation roughly doubles in thickness from $107 \mathrm{ft}$ in Clubhouse Crossroads \#1 to about $200 \mathrm{ft}$ throughout the Charleston-Mt. Pleasant area (section $A-A^{\prime}$ ). Most of the thickening occurs in the lower part of the unit, which consists of 10- to 30 -foot-thick coarse sands that alternate with finer grained sections. This west-to-east thickening of the Middendorf Formation, and the complementary thinning of the underlying Cape Fear Formation, suggest an erosional contact between the two units.

The Middendorf Formation is readily recognized on geophysical logs by the high resistivities of its sands, which contrast with the low resistivities of sands in the underlying Cape Fear Formation and with the low resistivities of fine-grained sections in the overlying Shepherd Grove Formation (see below). These differences in resistivity can be used to readily identify the Cape Fear-Middendorf contact in most wells. However, in some wells (for example $\mathrm{CHN}-185$, section $\left.B-B^{\prime}\right)$ the upper few sands of the Cape Fear have intermediate resistivities, which suggests groun twater mixing across the Cape Fear-Middendorf contact. At th? top of the Middendorf, the Ostrea cretacea sand and underlying fine-grained sediments form a distinctive coarsening-upward section that is readily recognized on logs throughout the Charleston-Mt. Pleasant area. In contrast, individual sands in the lower part of the formation cannot be traced with certainty between widely spared wells.

On the drillers logs from the studied water wells, the highest mention of coarse to gravelly sands within the Cretaceous section is typically (but not invariably) at the depth of the Crtrea cretacea bed at the top of the Middendorf, as interpreted independently from the geophysical logs (see sections). Similarly, in the cuttings from well $\mathrm{CHN}-635$, the highest occurrence of grave'ly, medium to very coarse sand is in the 1,823- to-1,812-ft sample, which corresponds to the top of the Middendorf as interpreted from the logs (sections $A-A^{\prime}, D-D^{\prime}$ ).

\section{Shepherd Grove Formation}

The type section of the Shepherd Grove Formation is the 1,754to 1,644-ft interval in the Clubhouse Crossroads \#1 core (Gohn, 1992). At Clubhouse Crossroads, the 110-foot-thick Shepherd Grove is a relatively homogeneous section of medium-light-gray to light-olive-gray, calcareous, silty clay, clayey silt, ard clayey very fine sand; these lithologies are thoroughly bioturbatod, microfossiliferous, and locally macrofossiliferous. A basal lag deposit consists of phosphate granules and small pebbles, very coarse sand, and bone fragments in a clayey matrix. The sharp lower contact of the Shepherd Grove Formation is between the lag $\mathrm{d}$ ?posit and the macrofossiliferous upper sand of the Middendorf Formation. The Shepherd Grove Formation is the oldest of seven lithologically similar, cyclic marine formations that constitute the Upper Cretaceous section above the Middendorf Formation. 
Microfossils are common throughout the Shepherd Grove Formation, and macroinvertebrates, principally mollusks, are common as prints and comminuted shell material. Gohn (1992) reviewed the available biostratigraphic data for the Shepherd Grove Formation in the Clubhouse Crossroads \#1 core (Hazel and others, 1977; Hattner and Wise, 1980) and assigned a Santonian and Campanian age to the unit, the Santonian-Campanian stage boundary being located near 1,695 $\mathrm{ft}$ in the core. Gohn (1992) proposed a subtidal-marine paleoenvironment for deposition of the Shepherd Grove sediments on the basis of their thorough bioturbation and common marine micro- and macrofaunas.

The Shepherd Grove Formation is the oldest unit to be fully penetrated by all drill holes used in this study. It maintains a thickness of about 110 to $120 \mathrm{ft}$ throughout most of the study area with slightly greater thicknesses (near $150 \mathrm{ft}$ ) present only at the northeastern end of section $D-D^{\prime}$.

Two coarsening-upward cycles within the Shepherd Grove Formation are apparent on the geophysical logs for wells in the Charleston-Mt. Pleasant area, for example the gamma-ray and electric logs for the wells on section $B-B^{\prime}$. The lower half of the Shepherd Grove section, excluding the thin basal lag deposit, grades upward from micaceous, calcareous silty clay to slightly coarser and slightly better sorted, calcareous, clayey silt and calcareous, clayey very fine sand. This gradation is reflected in upward-decreasing gamma-ray values and upward- increasing resistivities on the geophysical logs. This pattern is repeated in the upper half of the formation.

The Shepherd Grove Formation is recognized primarily by its fine- grained character, by the log patterns described in the previous paragraph, and by its stratigraphic position as the lowest of seven cyclic marine units in the Cretaceous section, being located immediately above the high-resistivity, coarse sands of the Middendorf Formation. The Shepherd Grove Formation and the overlying six fine-grained marine formations are difficult to differentiate using only water-well cuttings because of the repetition of a narrow range of lithologies within these units. However, the contacts of the Shepherd Grove with the Middendorf Formation and Caddin Formation are readily apparent in cored drill holes, as at Clubhouse Crossroads \#1 (Gohn, 1992) and on geophysical logs.

\section{Caddin Formation}

Gohn (1992) defined the type section of the Caddin Formation as the 100-foot-thick interval from 1,644 to $1,544 \mathrm{ft}$ in the Clubhouse Crossroads \#1 core. There, the Caddin Formation is a monotonous section of strongly bioturbated, calcareous, clayey, glauconitic quartz sand; the glauconite content increases significantly downward in the section. Abundant secondary carbonate nodules in which calcite replaces the primary clay matrix are characteristic of the Caddin section at Clubhouse Crossroads. These nodules vary in size from less than an inch in diameter to at least $2 \mathrm{ft}$ in some long core segments.

The lower contact of the Caddin Formation at Clubhouse Crossroads is a sharp, irregular, burrowed boundary. Glauconitequartz sand at the base of the Caddin fills burrows that extend down from the contact into sparingly glauconitic, micaceous, clayey fine sand in the upper part of the Shepherd Grove Formation.

The Caddin Formation contains common marine microfossils and typically comminuted mollusks. Calcareous nannofossils and planktic Foraminifera in the Caddin Formation and the overlying Cane Acre Formation of the Black Creek Group (Hazel and others,
1977; Hattner and Wise, 1980) establish an early Campanian age for the Caddin (fig. 3; Gohn, 1992). The per rasive bioturbation, common marine fossils, and absence of well-sorted sands suggest a offshore-marine paleoenvironment of deposition for the Caddin sediments at Clubhouse Crossroads (Gohn, 1992).

East of Clubhouse Crossroads, the Caddin Formation is lithologically heterogeneous and shows extreme thickness variations. Observed thicknesses range from as little as $40 \mathrm{ft}(\mathrm{CHN}-219$, section $\left.D-D^{\prime}\right)$ to slightly more than $200 \mathrm{ft}(\mathrm{CHN}-178$, section $\left.A-A^{\prime}\right)$. The thickest Caddin sections are in the vicinity of Charleston harbor (fig. 2), and the unit thins from there toward the northeast (sections $C-C^{\prime}$ and $D-D^{\prime}$ ) and the west (section $A-A^{\prime}$ ). Lithologies inferred from geophysical logs for the thicker Caddin sections include: a basal unit of moderately high resistivity that is interpreted to represent calcareous, clayey, gla:iconitic quartz sand similar to the Caddin section at Clubhouse Crossroads; a 10- to 20-foot-thick medial fine-grained unit that is readily correlated on resistivity logs where preserved (see minor bed correlations on sections); and an upper clayey quartz-sand unit.

Truncation of the contacts between these lithologic subdivisions by the upper contact of the Caddin accompanies the northeastward thinning of the formation on sections $C-C^{\prime}$ and $D-D^{\prime}$. For example, over $100 \mathrm{ft}$ of section is lost from the upper part of the Caddin from southwest to northeast along section $D-D^{\prime}$. These characteristics indicate that the Caddin-Cane. Acre contact is a low-angle, but high-relief, erosional unconformity that severely truncates the Caddin section in many areas. Examples of similar low-angle erosional unconformities involving Cretaceous marine sections are illustrated by Donovan and others $(1988$, fig. 3 ) and Van Wagoner and others (1990, fig. 24).

In the Charleston-Mt. Pleasant area, the 10 to $15 \mathrm{ft}$ of Caddin sediments immediately below the formatior's erosional upper contact constitute a zone of moderately high electrical resistivity that contrasts with lower resistivities in the overlying and underlying sediments. This zone is most apparent at th? top of the thick Caddin section in well $\mathrm{CHN}-178$ (section $A-A^{\prime}$ ) where it is known to be a high-density interval (from the gamma-gamma density log) that is uniquely designated on the driller's log as "white rock." This zone is considered to have a secondary origin because its position relative to the base of the Caddin varies greatly on the sections, owing to its association with the high-relief upper contact of the unit.

Although no core samples are available, this high-density, moderately high-resistivity zone at the top of the Caddin is provisionally interpreted as a secondary carborate-cemented interval that is similar, for example, to the Cenozoic high-density, high-velocity calcic paleosols inferred from geophysical logs by Hanneman and others (1992). The presence of a paleosol beneath the high-relief Caddin-Cane Acre contact would be consistent with a period of subaerial erosion between deposition of the Caddin and Cane Acre sections.

In the Clubhouse Crossroads \#1 core, secondary carbonate cementation is not limited to the top few feet of the Caddin Formation but instead is common throughout the full thickness of the formation in the form of secondary calcite nodules, as described above. Gamma-gamma and interval-transit-time logs for this corehole show the entire Caddin section to be a high-density, high-velocity interval that contrasts with lower velocity clays in the lower part of the overlying Cane Acre Formation. This velocity contrast at the Caddin-Cane Acre contact is anparent on seismicreflection lines in the study area where the corresponding reflector has been mapped as the K horizon by Hamilton and others (1983). 
The Caddin Formation is characterized by its position as the second cyclic marine unit above the lithologically distinctive Middendorf Formation, by its high-relief upper contact, and by its substantial secondary cementation. Recognition of these features could be difficult in a single isolated drill hole unless core samples or detailed resistivity, sonic, and density logs were available. Abundant secondarily cemented "limestone" chips in cuttings may eventually prove useful as a criterion for defining the top of the Caddin.

\section{Cane Acre Formation of the Black Creek Group}

Gohn (1992) defined the 1,544- to $1,344-\mathrm{ft}$ interval in the Clubhouse Crossroads \#1 core as the type section of the Cane Acre Formation, the oldest of four formations in the Black Creek Group (fig. 3). At Clubhouse Crossroads, the 200-foot-thick Cane Acre Formation consists of a lower clay member and an upper sand member. The clay member consists of light-olive-gray, bioturbated, micro- and macrofossiliferous, sparingly glauconitic silty clay, clayey silt, and clayey very fine sand. The silts and very fine sands, which occur only in the upper third of the clay member, grade across a broad interval into locally macrofossiliferous and cemented, well-sorted, fine to medium sand that constitutes most of the sand member. The contact between the two members is placed at $1,408 \mathrm{ft}$ in the Clubhouse Crossroads section; above this level, the gamma log indicates a minimal clay content in all but the upper $12 \mathrm{ft}$ of the sand member, which consist of less well sorted, medium-gray, clayey fine to medium sand (Gohn, 1992).

In the Clubhouse Crossroads section, a few inches of core containing the actual boundary between the Cane Acre Formation and the Caddin Formation were not recovered. The core segments closest to the contact interval consist of nodular, clayey fine sand in the Caddin and macrofossiliferous silty clay in the overlying Cane Acre Formation. Mollusks and calcareous microfossils are common to abundant in the clay member of the Cane Acre, and mollusks remain common in the sand member although they are preserved primarily as molds in cemented layers. Hazel and others (1977) and Hattner and Wise (1980) assigned a middle Campanian age to the section assigned by Gohn (1992) to the Cane Acre Formation. Gohn (1992) considered the Cane Acre Formation at Clubhouse Crossroads to be a dominantly regressive marine section in which fine-grained offshore deposits grade upward into a nearshoremarine sand.

Substantial variations in the thickness of the Cane Acre clay member complement thickness variations in the underlying Caddin Formation. That is, the Cane Acre clay member is thickest where the Caddin is thinnest and is thinnest where the Caddin is thickest. Higher in the section, the Cane Acre sand member thickens eastward from $64 \mathrm{ft}$ at Clubhouse Crossroads (DOR-37; section $A-A^{\prime}$ ' to locally more than $150 \mathrm{ft}$ along section $D-D$ '.

The Cane Acre Formation is characterized by its coarseningupward pattern on geophysical logs that reflects the gradation from the lower clay member to the upper sand member. Similar patterns also are present in the other six marine formations above the Middendorf Formation; however, the Cane Acre is the thickest of these units and has the most laterally continuous upper sand member.

\section{Coachman Formation of the Black Creek Group}

The type section of the Coachman Formation is the 1,344- to 1,214-ft interval in the USGS-Clubhouse Crossroads \#1 core (Gohn, 1992). The 130-ft-thick Coachman Formation at Clubhouse Crossroads is a relatively homogeneous section of greenish- gray to gray, calcareous silty clays, clayey silts, and very fine sands. There is a general trend within the section from moro clayey, finer grained deposits in the lower part of the unit to less clayey and slightly coarser grained deposits in the upper part. $T$-is coarseningupward trend resembles the trend in grain-size distribution in the underlying Cane Acre Formation at Clubhouse Crorsroads except that a well-sorted sand is not present in the upfer part of the Coachman, as there is in the upper part of the Cane Acre. The sharp lower contact of the Coachman is marked by a basal phosphate-pebble lag deposit that overlies the upper sand member of the Cane Acre Formation.

The Coachman sediments at Clubhouse Crossroads are strongly bioturbated and contain common calcareous micri- and macrofossils. Hazel and others (1977) and Hattner and Wise (1980) assigned a middle and late Campanian age to the section assigned by Gohn (1992) to the Coachman Formation. The Coachman Formation is a dominantly regressive marine section in which poorly sorted, fine-grained offshore deposits are overlain by slightly better sorted and coarser grained sediments that wero deposited in a more nearshore environment.

In the eastern part of the study area, the Coachman Formation contains a lower clay member and an upper sand member similar to those defined for the Cane Acre Formation at Clubhouse Crossroads (Gohn, 1992). Considerable variation : in the thicknesses of these members are apparent on section $A-A^{\prime}$. The sand member is absent in the Coachman (undivided) at Clubhouse Crossroads but constitutes most of the Coachman section in wells $\mathrm{CHN}-172$ and $\mathrm{CHN}-178$ and about half of the formation at the eastern end of the section.

Variations in the thickness and log characteristics of the sand member are also common on the other sections. For example, the contact between the sand member and the clay member may be locally sharp or gradational, either one or two individual sand bodies may be present in the sand member, and the geophysical logs for those sand bodies indicate both coarsenirg-upward and fining-upward patterns. Thickness variations of the clay member complement those of the sand member; that is, thinner sections of the clay member underlie the thicker sections of the sand member.

These characteristics suggest the possibility that the upper sand member of the Coachman may have a composite origin, consisting of sandy valley-fill deposits cut into nearshore-marine sands. Alternatively, these variations in member thickness and log signatures may simply reflect local variations in sedimen+ supply within a dominantly regressive marine section.

The Coachman Formation is recognized on geophysical logs by significant variations in the thickness and log signature of its upper sand member and by its stratigraphic position as the second cyclic marine unit above the highly eroded top of the Cad lin Formation. A moderate to large spike on the gamma-ray logs marks the basal phosphate-pebble bed of the Coachman and const tutes a distinctive log signature that is discernible to varying degrees in the studied wells. The downward change from silty cle? in the lower part of the overlying Bladen Formation to silt or vary fine to fine sand in the upper part of the Coachman might 1 ? apparent in some sets of cuttings, however, this change is rare $y$ apparent on the available drillers logs.

\section{Bladen Formation of the Black Creek Group}

Owens (1989; also see Sohl and Owens, 1991) defined the Bladen Formation from outcrop sections along the Cape Fear River in North Carolina. This unit was extended to the subsurface of the Charleston area by Gohn (1992), who assigned the section 
from 1,214 to $1,072 \mathrm{ft}$ in the USGS-Clubhouse Crossroads \#1 core to the Bladen. At Clubhouse Crossroads, the basal few feet of the Bladen consist of macrofossiliferous, clayey, sparingly phosphatic, fine to medium sand that sharply overlies silty very fine sand at the top of the Coachman Formation. The lower half of the 142-foot-thick Bladen Formation above the thin basal sand consists of gray to gray-green, calcareous silty clay and clayey silt, whereas the upper half is a poorly sampled section of gray, calcareous, clayey and silty very fine sand that is locally cemented with secondary calcite. The gamma-ray log for the USGSClubhouse Crossroads \#1 corehole (DOR- 37, section $A-A^{\prime}$ ) illustrates this upward trend from poorly sorted, clayey deposits to slightly coarser grained and better sorted deposits.

Marine microfossils and typically comminuted macrofossils are common in the Bladen Formation. Gohn (1992) assigned a late Campanian age to the Bladen on the basis of fossils described primarily by Hazel and others (1977) and Hattner and Wise (1980). The Bladen Formation is the third highest cyclic marine unit in the Black Creek Group, consisting of a lower fine-grained offshore-marine section that grades up into slightly coarser grained and better sorted nearshore-marine sediments.

East of Clubhouse Crossroads, the Bladen Formation consists of a lower clay member and an upper sand member similar to those in the underlying Cane Acre and Coachman Formations (Gohn, 1992). The clay member dominates the Bladen section throughout the study area with thicknesses locally exceeding $150 \mathrm{ft}$ (see section $\left.D-D^{\prime}\right)$. The sand member typically does not exceed $50 \mathrm{ft}$ in thickness and is absent at the eastern end of section $D-D^{\prime}$ as well as at Clubhouse Crossroads.

In wells located east of Charleston Harbor (fig. 2), the electric logs indicate a moderately sharp clay-over-sand contact slightly above the Coachman-Bladen contact drawn on the sections (for example, see section $\left.B-B^{\prime}\right)$. The formational contact was drawn at the base of a gamma-ray spike (interpreted as a phosphateglauconite lag deposit) that is found 10 to $20 \mathrm{ft}$ below the clay-sand contact determined from the electric logs. This interpretation places a sand-dominated section at the base of the Bladen that may be similar to thinner sections of megafossiliferous clayey sand at the bases of the Bladen Formation and the Donoho Creek Formation in the Clubhouse Crossroads core.

The Bladen Formation is recognized by its stratigraphic position as the third cyclic, dominantly coarsening-upward, marine unit above the highly eroded top of the Caddin Formation. The Bladen is also characterized by the greater thickness of its lower clay member relative to the thickness of its upper sand member, and by the presence locally of a thin sandy unit at its base.

\section{Donoho Creek Formation of the Black Creek Group}

The Donoho Creek Formation was originally defined by Owens (1989; also see Sohl and Owens, 1991) from outcrop sections along the Cape Fear River of North Carolina. Gohn (1992) later recognized this unit in the subsurface of South Carolina, assigning the section from 1,072 to $873 \mathrm{ft}$ in the USGS-Clubhouse Crossroads \#1 core to the Donoho Creek. In this core, the basal $10 \mathrm{ft}$ of the Donoho Creek Formation consists of bioturbated, megafossiliferous, clayey, medium-gray, fine to medium sand. The remainder of the unit consists of light-olive-gray to medium-gray, calcareous clayey silt, silty clay, and clayey fine sand. These sediments are typically bioturbated and micro- and macrofossiliferous. The contact of the Donoho Creek Formation with the underlying Bladen Formation was picked primarily on the basis of the geophysical logs because the basal foot of the Donoho Creek and much of the upper part of the Bladen were not recovered in cores.

Gohn (1992) assigned an early Maastrichtian age to the Donoho Creek on the basis of calcareous microfossils and mollusks discussed by Hazel and others (1977) and Hattner and Wise (1980). The abundant bioturbation and common planktic marine faunas and floras, as well as the absence of well-sorted sands, indicate offshore-marine deposition for the Donoho Creek section at Clubhouse Crossroads.

The Donoho Creek Formation also does not contain any well-sorted sands in its upper part in the area east of Clubhouse Crossroads. This absence of an upper sand member may result from truncation of the Donoho Creek section ty erosion along the base of the overlying Peedee Formation. For example, erosion of the top of the Donoho Creek is apparent on section $B-B^{\prime}$ where the base of the Peedee Formation lies at progressively lower stratigraphic levels within the Donoho Creek in the updip direction. Regionally, the Donoho Creek thins from the Clubhouse Crossroads \#1 area to the eastern end of the study area (see sections $A-A^{\prime}$ and $C-C^{\prime}$ ).

Multiple 20- to 80-foot-thick coarsening-'upward cycles are recognizable within the Donoho Creek Formation on most of the studied geophysical logs. On the basis of the gamma-ray logs, each cycle appears to grade from a lower silty clay to an upper clayey silt or clayey fine sand. For example, two comparatively heterogeneous cycles are discernible below a lithologi ally homogeneous upper cycle in the Donoho Creek section at Clubhouse Crossroads (DOR-37, section $A-A^{\prime}$ ).

The Donoho Creek Formation in the study area is characterized by the absence of an well-sorted upper sand member, the presence of which is typical of the other formations in the Black Creek Group, and by the presence of multiple internal coarseningupward cycles. It is the fourth cyclic marine unit above the highly eroded top of the Caddin Formation.

\section{Peedee Formation}

The original definition of the Peedee Formation in the USGSClubhouse Crossroads \#1 core (Gohn and others, 1977) was substantially modified by Gohn (1992). The Feedee Formation is now defined as the 73-foot-thick section from a depth of $873 \mathrm{ft}$ to the Cretaceous-Tertiary boundary at $800 \mathrm{ft}$. In the core, the lower $10 \mathrm{ft}$ of the Peedee Formation consists of light-olive-gray, massive, calcareous, clayey and silty, fine to medium sand that contains common microfossils and several percent of coarse to very coarse quartz sand and sand-sized phosphate and glauconite. This basal unit grades up into $43 \mathrm{ft}$ of similar appearing, typically massive to bioturbated, microfossiliferous silty clay and clayey silt. The upper $20 \mathrm{ft}$ of the Peedee consists of macrofossiliferous, locally calcitecemented, clayey silt and very fine to fine sant.

The lower contact of the Peedee Formation is sharp between the poorly sorted, relatively coarser sand at the bas? of the Peedee and calcareous clayey silt to very fine sand at the top of the underlying Donoho Creek Formation. The upper contact of the Peedee Formation with overlying Paleocene deposits is sharp between the indurated shelly fine sand at the top of the Pee lee and glauconitic, micaceous, microfossiliferous, clayey silt and fine sand containing secondary calcite nodules in the lower part of the overlying Paleocene section.

Calcareous microfossils and macrofossils are common to locally abundant throughout the Peedee Formation in the Clubhouse Crossroads \#1 core. Gohn (1992) assigned a late early Maastrichtian and middle to late(?) Maastrichtian age tc the Peedee on the basis of planktic faunas and floras described $t y \mathrm{Hazel}$ and others 
(1977) and Hattner and Wise (1980). Gohn (1992) inferred a shallow-marine paleoenvironment for deposition of the Peedee sediments.

The Peedee Formation maintains a thickness of about 50 to 75 $\mathrm{ft}$ throughout the study area. Electric logs for this dominantly finegrained section are typically mundane, whereas the Peedee is readily recognized by its characteristically high radioactivity on gamma-ray logs. The gamma-ray logs typically show a large spike at the base of the Peedee Formation and a similar spike at the base of the overlying Paleocene section. Gamma-ray values within the Peedee are also high with an additional large spike also present about 10 to $20 \mathrm{ft}$ above the basal spike. On some Peedee logs, the two lower spikes appear as one thick high-radiation interval. These high radioactivity values are attributed to phosphate-glauconite lag deposits at the bases of the Peedee and the Paleocene and to locally high phosphate contents elsewhere in the Peedee. The high radiation in these deposits results from the relative concentration of radiogenic isotopes in phosphate (uranium, thorium) and glauconite (potassium). In summary, the Peedee Formation is characterized in the study area by its distinctively high gamma values, by the general absence of a thick well-sorted sand member, and by its stratigraphic position at the top of the Cretaceous section.

\section{GEOHYDROLOGY}

\section{PHYSICAL CHARACTERISTICS, ORIGINS, AND WATER-BEARING PROPERTIES OF THE CRETACEOUS SANDS}

Cretaceous sands of the study area can be placed into three categories on the bases of sand-body geometry, petrologic characteristics, lithologic associations, and inferred origins. Contrasting geohydrologic properties are associated with these categories. The categories are: 1) thin (less than $10 \mathrm{ft}$ ), calcareous and glauconitic, poorly sorted to moderately well sorted, very fine to fine sands found within dominantly fine-grained offshore-marine sections; II) thin to moderately thick ( 5 to $30 \mathrm{ft}$ ), typically feldspathic, sparingly calcareous to noncalcareous, poorly sorted to well sorted, coarse and gravelly coarse sands deposited in fluvial or estuarine channels; and III) moderately thick to very thick (20 to $150 \mathrm{ft}$ ), calcareous and glauconitic, moderately well sorted to well-sorted, very fine to medium sands deposited in nearshore-marine environments.

Sands of category I are typical of the Clubhouse, Shepherd Grove, Caddin, and Peedee Formations and the dominantly fine-grained lower clay members of the four formations in the Black Creek Group. These sands are interbedded in offshoremarine sections with poorly sorted silty and sandy clays and clayey silts where they likely represent sedimentation during short-term, high-energy events. The poor sorting and thinness of category-I sands make them unlikely candidates for ground-water production, even in intervals where they are abundant (for example, the upper part of the lower clay member of the Cane Acre Formation in well CHN-559, section $\left.B-B^{\prime}\right)$.

Category-I sands as thin as 1 to $2 \mathrm{ft}$ can be traced between closely spaced wells if geophysical logs having adequate bed resolution are available. The single-point resistivity logs available from some water wells in the study area are adequate for this purpose; gamma-ray, spontaneous potential, and short-normal resistivity logs can be used to trace the thicker sands of this category.

Some category-I sands are secondarily cemented with calcite, which tends to produce higher values on resistivity logs than inight otherwise be expected from these relatively poorly soted deposits. Therefore, these partially cemented zones resemble better sorted, freshwater sands on the resistivity logs (for example, the uppermost part of the Shepherd Grove Formation on section $B-B^{\prime}$. However, the cemented category-I sands can be differentiated from better sorted sands by their (category I) higher values on gamma-ray logs; for example, compare the gamma-log signature for the highresistivity upper part of the Shepherd Grove Formation with the gamma-log signatures of the Middendorf and upper Cane Acre sands in well CHN-185 (section $B-B^{\prime}$ ).

Category-Il sands are present in the Cape Fear Formation and the lower one-half to two-thirds of the Middendorf Formation. Cape Fear sands form the lower parts of the 10- to 30-foot-thick fining upward cycles that characterize this formation. These sands have sharp erosional bases and grade upward into si'ty and sandy clays that are truncated by the basal sand of the next-higher cycle. In some cases, amalgamated sands occur where the sand of one cycle lies on the sand of a severely eroded underlyins cycle. These cycles represent the meandering channels and associated finegrained overbank deposits of a mixed-load fluvial or estuarine system. In keeping with their channel origin, individual Cape Fear sands generally can be traced only between closely spaced wells.

Channel sands in the lower part of the Middendorf Formation have origins and geometries similar to those of th? Cape Fear sands but differ significantly in other properties. Whereas the Cape Fear sands tend to have high clay contents, which may be derived secondarily in large part from the alteration of detrita' feldspar, the Middendorf sands are distinctly better sorted. Accordingly, porosities typically are higher in Middendorf sands than in Cape Fear sands. In addition, individual sand bodies and amalçamated sand intervals are typically thicker in the Middendorf thar in the Cape Fear. As a result of these factors, the category-II sand s of the lower part of the Middendorf constitute the most frequently used waterproducing interval in the Charleston area.

Category-III sands include the upper Ostrea cretacea-bearing sand at the top of the Middendorf Formation and th? upper sand members of the Cane Acre, Coachman, and Bladen Formations of the Black Creek Group. These units are know to consist of bioturbated, macrofossiliferous, fine-to-medium (rarely coarse) sands and are typically interpreted to be nearshore-marine deposits.

The upper Middendorf sand does not change greatly in thickness, in lithology (as observed in cuttings), or in its log characteristics across the study area. However, significant changes in thickness and log characteristics are common in the upper sand members of the formations of the Black Creek Group. The most obvious example is the Coachman Formation on section $A-A^{\prime}$. The Coachman does not contain a well-sorted sand unit at Clubhouse Crossroads (DOR-37) but consists almcst entirely of sand in wells $\mathrm{CHN}-172$ and $\mathrm{CHN}-178$. In wells $\mathrm{CHN}-163$ and CHN-635 at the eastern end of section $A-A^{\prime}$, th? Coachman consists of sand units overlying fine-grained sediments. These variations in sand content could be related to changes in energy and sediment supply in coeval nearshore-marine paleoenvironments such as those found in a delta-front setting. However, these variations also could represent, in part, the deposition of areally restricted, sand-dominated sections in eroded paleovalleys cut into the tops of older sandy nearshore-marine sections (see Van Wagoner and others, 1990, for discussion of incised-valley fill sedimentation). Hence, a dual origin (category-II sands incised into category-III sands) is possible for the upper sand members of some or all of the formations of the Black Creek Group. 
Despite their considerable thicknesses and lateral extents, category-III sands are relatively untested as ground-water resources in the Charleston area. The uppermost sand of the Middendorf Formation, which is typically screened along with the category-II sands of the lower part of the Middendorf, is an obvious exception.

\section{PRINCIPAL AQUIFER OF CRETACEOUS AGE}

The principal Cretaceous aquifer underlying the Charleston area (figs. 1,2) primarily consists of the coarse-grained, category II and category III sands of the Middendorf Formation. However, clayey calcareous sands in the upper part of the Shepherd Grove Formation above the Middendorf and coarse sands that occur in the sand-clay cycles of the Cape Fear Formation below the Middendorf (fig. 3) may be locally connected hydraulically to the Middendorf sands. In this report, the commonly used term "Middendorf aquifer" is retained for this interval although we recognize the stratigraphically complex nature of this geohydrologically defined unit.

Previous investigators have assigned various names to the principal aquifer in sands of Cretaceous age underlying Charleston at depths of 1,800 to $2,000 \mathrm{ft}$, which is referred to here as the Middendorf aquifer. Darton (1896) considered these water-bearing sands to be part of the Lower Cretaceous Potomac Group. Stephenson (1914), in his description of a well drilled at Charlotte Street for the Charleston Consolidated Railway and Lighting Company ( $\mathrm{CHN}-14)$, considered these sands to be part of the Black Creek Formation. Cooke (1936) also listed the Charlotte Street well as being open to sands of the Black Creek Formation. Siple (1946) describes deep wells on Sullivans Island as being open to the Tuscaloosa aquifer, implying a geologic correlation with the Tuscaloosa Formation of the Gulf of Mexico Coastal Plain. More recently, Colquhoun and others (1983) published hydrogeologic sections showing deep wells in the study area to be open to the Middendorf aquifer. Park (1985) assigned most of the screened and open intervals in the deep water wells of the Charleston area to the Black Creek aquifer, and Aucott and Speiran (1985) considered these wells to be open primarily to the Middendorf aquifer.

Aquifers in the Cretaceous sands have a long history of use in the area dating to about 1850 when the first well was drilled to $1,260 \mathrm{ft}$ into sands that are now assigned to the Coachman Formation (Lynch and others, 1881). This well flowed at 30 $\mathrm{gal} / \mathrm{min}$, and the water level was at $24 \mathrm{ft}$ and $10 \mathrm{in}$. above land surface. A well was completed into the Middendorf aquifer in 1879 in Marion Square, Charleston; this well flowed until the fall of 1989. When it was completed, the Marion Square well flowed at a rate of $465 \mathrm{gal} / \mathrm{min}$ and supplied a large portion of the water needs of the city, including the well-known fountains on Calhoun Street and Meeting Street. Four more wells were completed in this aquifer by 1897; however, each new well produced successively less water due to well interference, and the city was soon forced to turn to surface water for its potable water source.

\section{Current Use}

In recent years, several towns in the Charleston area have turned to the Middendorf aquifer as the most economical source of potable water. The larger of the towns, Mount Pleasant and Summerville, are experiencing rapid population growth and concurrent increased demand for water. In 1969, Mount Pleasant drilled the first of six wells open to the Middendorf aquifer that now provide the town's only source of potable water. In early 1992, these wells produced an average of 4.6 million gallons per day (Mgal/d) of water, which was treated with reverse-osmosis technology to lower its total dissolved solids concentration. Summerville (fig. 1) began a deep- well installation program in 1979 when it drilled the first of five wells to be completet in the Middendorf aquifer. These wells produce an average of $4 \mathrm{Mgal} / \mathrm{d}$ of water which is supplemented at times by surface water from the Edisto and Ashley Rivers. Other municipal users of water from the Middendorf aquifer in the area are Sullivan-Island and Isle of Palms (fig. 2) as well as St. Stephen in northern Berkeley County and Walterboro in Colleton County. In addition, wells completed in the Middendorf aquifer supply irrigation water at Kiawah Island and Seabrook Island in southern Charleston County and at Wild Dunes resort on the Isle of Palms.

Most deep wells in the area east of the Cooser River (fig. 2) are open to the Middendorf aquifer. Yields range from 350 to 1,600 $\mathrm{gal} / \mathrm{min}$ with up to $300 \mathrm{ft}$ of drawdown. Trans nissivities calculated from single-well tests range from 1,200 to 1,6$) 0 \mathrm{ft}^{2} / \mathrm{d}$ (Aucott and Newcome, 1986). Predevelopment water levels were as much as $126 \mathrm{ft}$ above sea level, and predevelopment flow was parallel to the coast toward the Myrtle Beach area of northeastern South Carolina (Aucott and Speiran, 1985). Pumping began on Sullivans Island in 1904 when the U.S. Army constructed a 2,000-foot-deep well for water supply. A second Sullivans Islard well was drilled in 1944 after problems developed with the first one. These wells apparently had little effect on the potentiometric surface in the area. The potentiometric surface at one of the Mount Pleasant wells (CHN-173, fig. 2) was about $126 \mathrm{ft}$ abore sea level when it was drilled in 1971.

\section{Water-Level Declines}

In recent years, concentrated pumping, combined with the low transmissivities of the Middendorf aquifer, has profoundly altered the predevelopment southwest-to-northeast ground-water flow path. By November 1991, a large cone of depression in the potentiometric surface was centered on the Mount Pleasant area (fig. 4) where the water level in well $\mathrm{CHN}-559$ was $48 \mathrm{ft}$ below sea level (fig. 2). A similar depression with a minim' $x$ m water level of 40 ft below sea level (well DOR-221, not shown) was centered in the Summerville area. These two depressions in the potentiometric surface are beginning to coalesce into a large regional cone of depression that extends over a large part of $C^{\prime}$-arleston, Berkeley, and Dorchester Counties.

The water level in well $\mathrm{CHN}-14$, completed in the top (category III) sand in the Middendorf aquifer in downtown Charleston city (CHN-14, fig. 2), has been monitored continuously since April, 1990. A plot of these water levels over time illustrates the magnitude of water-level declines due to pumping in Mount Pleasant. A water level of about $90 \mathrm{ft}$ above sea level was recorded in 1911 when this well was installed. At that time, it reportedly flowed at $428 \mathrm{gal} / \mathrm{min}$ with a water temperature of 99.75 degrees Fahrenheit (Stephenson, 1914). The depth of the well was 2,001 ft when it was installed in 1911; however, no screen was set in the well, and it has since collapsed below the bot'om of the casing at a depth of 1,866 feet. Correlations based on geophysical logs run in 1990 indicate that the top of the Middendorf Formation in $\mathrm{CHN}-14$ is at a depth of $1,800 \mathrm{ft}$.

The hydrograph of water levels in well $\mathrm{CHN}^{\mathrm{N}}-14$ is plotted along with the pumpage in millions of gallons per day (Mgal/d) for the closest Mount Pleasant well (CHN-167; fig. 2) and the total Mount Pleasant pumpage (fig. 5). The plot indicates a close correlation between the amount of water pumped at $\mathrm{CHN}-167$ and the water 


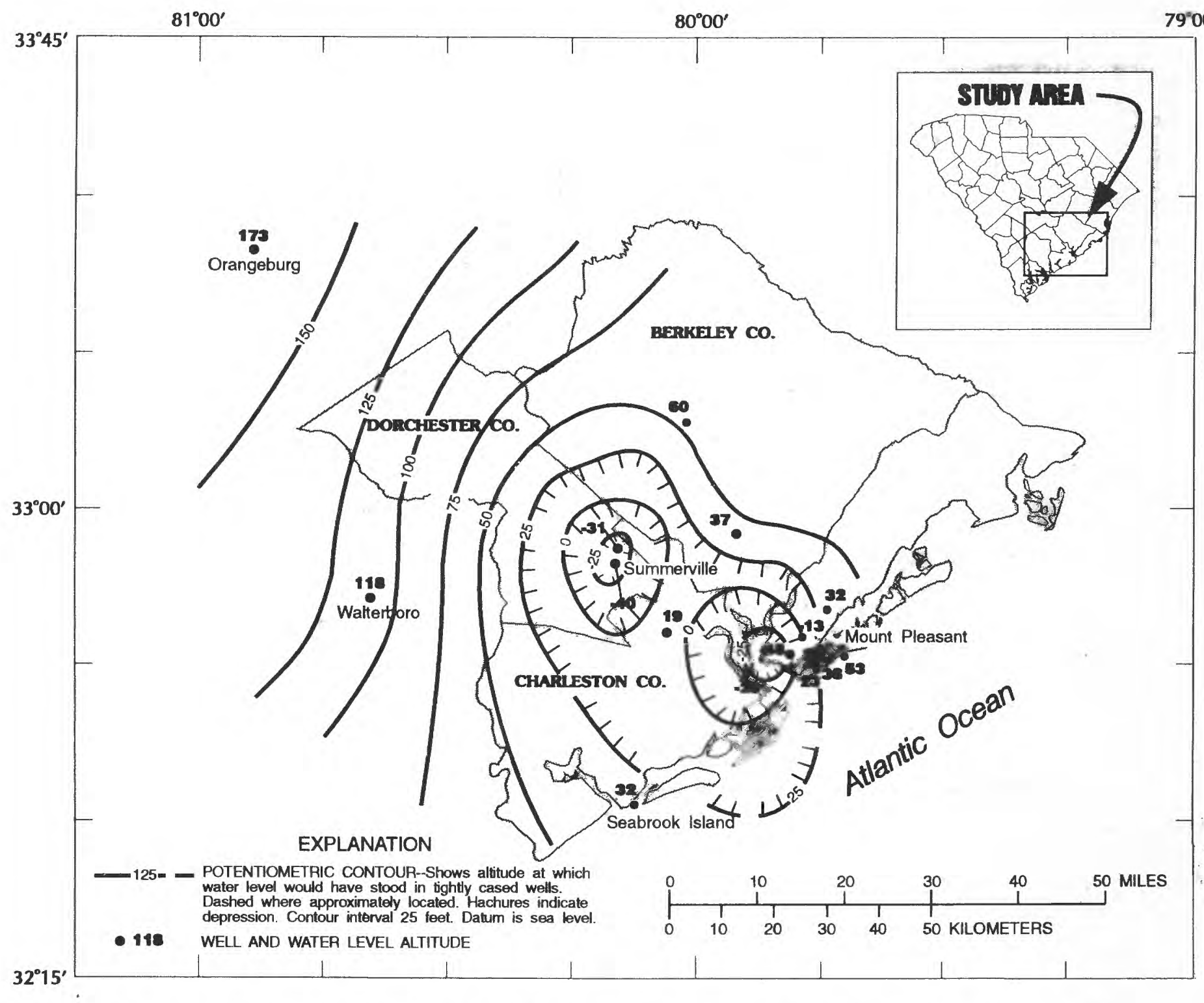

Figure 4. - Potentiometric surface of the Middendorf aquifer in Charleston, Dorchester, and Berkeley Counties, November, 1991.

level in well $\mathrm{CHN}-14$. When the pumpage is less than $2 \mathrm{Mgal} / \mathrm{d}$, the water level in CHN-14 tends to rise. During the fall of 1990 and the winter of 1991, the water level in well $\mathrm{CHN}-14$ rose from $12 \mathrm{ft}$ below land surface to $2 \mathrm{ft}$ below land surface. In May of 1991, well $\mathrm{CHN}-167$ was out of service for maintenance and a pump upgrade. When well CHN-167 was placed back in service in June 1991 and pumped at a steady $1,600 \mathrm{gal} / \mathrm{min}$, the water level in $\mathrm{CHN}-14$ declined from $2 \mathrm{ft}$ below land surface to $54.81 \mathrm{ft}$ below land surface as of July 13, 1993. Water levels in other Middendorf wells in the Charleston area also declined during this period. These declines are a function of the large ground-water withdrawals in the area and the physical complexity of the Cretaceous sedimentary section, as described in this report. These factors may have a profound effect on water levels and the ground-water flow regime in the Cretaceous aquifers.

Possibly the greatest effect of the observed variations in sandbody geometries would be to lower the amount of effective recharge from the outcrop areas of the Cretaceous aquifers. Instead of a continuous sand body from the recharge area to the modern coastal area, a large part of each sand aquifer would in reality consist of fine-grained material due to its complex depositional history. This would increase the length of the flow paths in the aquifer and probably reduce the amount of water available for recovery in wells. This property could be one characteristic of the aquifer systems that has contributed to large water-level declines in the study area. 


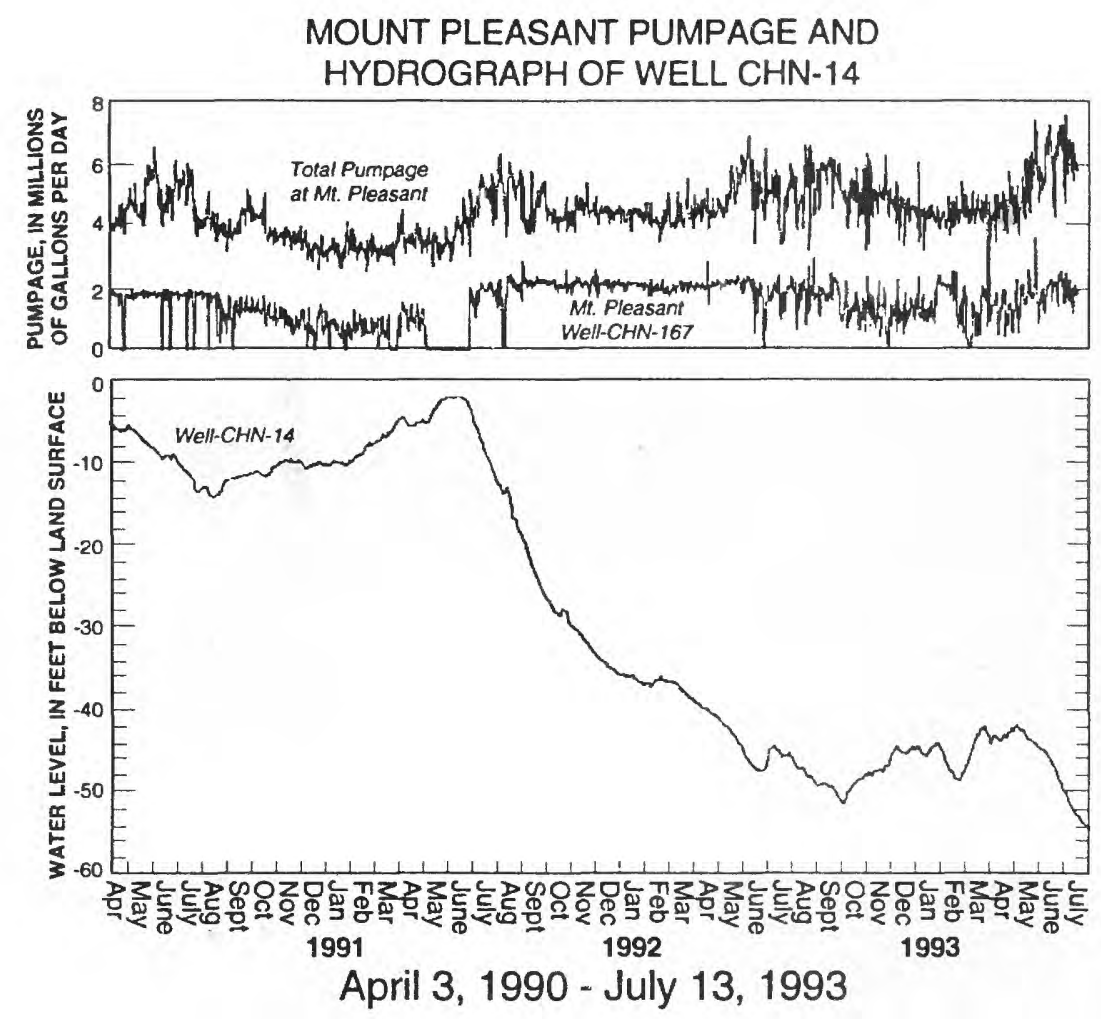

Figure 5.-Mount Pleasant pumpage compared to hydrograph of well $\mathrm{CHN}-14$ from April 3, 1990, to October 22, 1992.

\section{REFERENCES CITED}

Aucott, W.R., and Newcome, Roy, Jr., 1986, Selected aquifer-test information for the Coastal Plain aquifers of South Carolina: U.S. Geological Survey Water-Resources Investigations Report 86-4159, $30 \mathrm{p}$.

Aucott, W.R., and Speiran, G.K., 1985, Ground water flow in the Coastal Plain aquifers of South Carolina: Journal of Groundwater, v. 23, no. 6, p. 736-745.

Aucott, W.R., Davis, M.E., and Speiran, G.K., 1987, Geohydrologic framework of the Coastal Plain aquifers of South Carolina: U.S. Geological Survey Water-Resources Investigations Report 85-4271, 7 plates.

Brown, P.M., Brown, D.L., Reid, M.S., and Lloyd, O.B., Jr., 1979, Evaluation of the geologic and hydrologic factors related to the waste-storage potential of Mesozoic aquifers in the southern part of the Atlantic Coastal Plain, South Carolina and Georgia: U.S. Geological Survey Professional Paper 1088, $37 \mathrm{p}$.

Colquhoun, D.J., Woollen, I.D., Van Nieuwenhuise, D.S., Padgett, G.G., Oldham, R.W., Boylan, D.C., Bishop, J.W., and Howell, P.D., 1983, Surface and subsurface stratigraphy, structure, and aquifers of the South Carolina Coastal Plain: Columbia, State of South Carolina, Report to the Department of Health and Environmental Control, $78 \mathrm{p}$.

Cooke, C.W., 1936, Geology of the Coastal Plain of South Carolina: U.S. Geological Survey Bulletin 867, 196 p.

Darton, N.H., 1896, Artesian well prospects in the Atlantic Coastal Plain region: U.S. Geological Survey Bulletin 138, 232 p.

Donovan, A.D., Baum, G.R., Blechschmidt, G.L., Loutit, T.S., Pflum, C.E., and Vail, P.R., 1988, Sequence stratigraphic setting of the Cretaceous-Tertiary boundary in central Alabama, in Wilgus, C.K., Hastings, B.S., Kendall, C.G. St. C., Posamentier, H.W., Ross, C.A., and Van Wagoner, J.C., eds., Sea-level changes: An integrated approach: Society of Economic Paleontologists and Mineralogists Special Publication No. 42, p. 299-307.

Fallaw, W.C., Thayer, P.A., and Price, V., 1990, Basal Coastal Plain deposits in southwestern South Carolina [abs.]: Geological Society of America Abstracts with Programs, v. 22, no. 4, p. 13.

Gohn, G.S., 1992, Revised nomenclature, definitions, and correlations for the Cretaceous formations in USGS-Clubhouse Crossroads \#1, Dorchester County, South Carolina: U.S. Geological Survey Professional Paper 1518, 39 p.

Gohn, G.S., and Campbell, B.G., 1992, Recent revisions to the stratigraphy of subsurface Cretaceous sediments in the Charleston, South Carolina area: South Carolina Geology, v. 34 , nos. 1 and 2, p. 25-38.

Gohn, G.S., Higgins, B.B., Smith, C.C., and Owens, J.P., 1977, Lithostratigraphy of the deep corehole (Clubhouse Crossroads corehole 1) near Charleston, South Carolina, in Rankin, D.W., ed., Studies related to the Charleston, South Carolina, earthquake of $1886-$ A preliminary report: U.S. Geological Survey Professional Paper 1028, p. 59-70.

Gohn, G.S., Christopher, R.A., Smith, C.C., and Owens, J.P., 1978, Preliminary stratigraphic cross sections of Atlantic Coastal Plain sediments of the southeastern United StatesCretaceous sediments along the South Carolina coastal margin: U.S. Geological Survey Miscellaneous Field Studies Map MF-1015-A. 
Hamilton, R.M., Behrendt, J.C., and Ackermann, H D., 1983, Land multichannel seismic-reflection evidence for tectonic features near Charleston, South Carolina, in Gohn, G.S., ed., Studies related to the Charleston, South Carolina, earthquake of 1886-Tectonics and seismicity: U.S. Geological Survey Professional Paper 1313, p. [1-I18.

Hanneman, D.L., Wideman, C.J., and Halvorson, J., 1992, Paleosols: Their use in well log correlation and seismic stratigraphy in Cenozoic basin-fill, southwestern Montana [abs.]: Geological Society of America Abstracts with Programs, v. 24, no. 7, p. A230.

Hattner, J.G., and Wise, S.W., Jr., 1980, Upper Cretaceous calcareous nannofossil biostratigraphy of South Carolina: South Carolina Geology, v. 24, no. 2, p. 41-117.

Hazel, J.E., Bybell, L.M., Christopher, R.A., Frederiksen, N.O., May, F.E., McLean, D.M., Poore, R.Z., Smith, C.C., Sohl, N.F., Valentine, P.C., and Witmer, R.J., 1977, Biostratigraphy of the deep corehole (Clubhouse Crossroads 1) near Charleston, South Carolina, in Rankin, D.W., ed., Studies related to the Charleston, South Carolina, earthquake of 1886-A preliminary report: U.S. Geological Survey Professional Paper 1028 , p. $71-89$.

Heron, S.D., Jr., Swift, D.J.P., and Dill, C.E., Jr., 1968, Graded rhythmic bedding in the Cape Fear Formation, Carolina Coastal Plain: Sedimentology, v. 11, p. 39-52.

Lynch, P.N., Shepard, C.V., Geddings, J.F.M., 1881, Artesian wells 1823-1879, Municipal report of the City of Charleston, SC, p. 197-313.

Owens, J.P., 1989, Geologic map of the Cape Fear region, Florence $1^{\circ} \times 2^{\circ}$ quadrangle and northern half of the Georgetown $1^{\circ} \times 2^{\circ}$ quadrangle, North Carolina and South Carolina: U.S. Geological Survey Miscellaneous Investigations Map [-1948-A, scale 1:250,000.

Park, A.D., 1985, The ground-water resources of Charleston, Berkeley, and Dorchester counties, SC: South Carolina Water Resources Commission Report 139, 146 p.
Prowell, D.C., Christopher, R.A., Edwards, L.E., Bytell, L.M., and Gill, H.E., 1985, Geologic section of the updip Coastal Plain from central Georgia to western South Carolina: U.S. Geological Survey Miscellaneous Field Studies M $\approx$ MF-1737, $10 \mathrm{p}$

Reid, M.S., Aucott, W.R., Lee, R.W., and Renken. R.A., 1986, Hydrologic and geologic analysis of a well in Dorchester County, South Carolina: U.S. Geological Survey WaterResources Investigations Report 86-4161, $23 \mathrm{~F}$.

Siple, G.E., 1946, Progress report on ground-water investigations in South Carolina: South Carolina Research, Planning, and Development Board Bulletin 15, 115 p.

Sohl, N.F., and Owens, J.P., 1991, Cretaceous stratixraphy of the Carolina Coastal Plain, in Horton, J.W., Jr., and Zullo, V.A., eds., The Geology of the Carolinas (50th annive"sary volume, Carolina Geological Society): Knoxville, Tenn., University of Tennessee Press, p. 191-220.

Stephenson, L.W., 1914, A deep well at Charleston, South Carolina: U.S. Geological Survey Professional Pc per 90-H, p. 69-94

Valentine, P.C., 1982, Upper Cretaceous subsurface stratigraphy and structure of coastal Georgia and South Carolina: U.S. Geological Survey Professional Paper 1222, 33 p.

1984, Turonian (Eaglefordian) stratigraphy of the Atlantic Coastal Plain and Texas: U.S. Geological Survey' Professional Paper 1315, $21 \mathrm{p}$.

Van Wagoner, J.C., Mitchum, R.M., Campion, K.M., and Rahmanian, V.D., 1990, Siliciclastic sequence stratigraphy in well logs, cores, and outcrops: Concepts for high-resolution correlation of time and facies: American Association of Petroleum Geologists Methods in Exploration Series, No. 7, 55 p.

CONVERSION FACTORS AND VERTICAL DATUM

\begin{tabular}{rll}
\hline Multiply & \multicolumn{1}{c}{ By } & To Obtain \\
\hline inch (in.) & $\mathbf{0 . 0 2 5 4}$ & meter \\
foot (ft) & $\mathbf{0 . 3 0 4 8}$ & meter \\
gallon per minute (gal/min) & $\mathbf{0 . 0 6 3 9}$ & liter per second \\
million gallons per day (Mgal/d) & $\mathbf{0 . 0 0 3 7 8 5}$ & cubic meters per day \\
\hline
\end{tabular}

Water temperatures in degrees Fahrenheit $\left({ }^{\circ} \mathrm{F}\right)$ can be converted to degrees Celsius $\left({ }^{\circ} \mathrm{C}\right)$ by using the following equation: ${ }^{\circ} \mathrm{C}=5 / 9 \times\left({ }^{\circ} \mathrm{F}-32\right)$

Transmissivity: The standard unit for transmissivity is cubic foot per day per square foot times foot of aquifer thickness $\left[\left(\mathrm{ft}^{3} / \mathrm{d}\right) / \mathrm{ft}^{2}\right] \mathrm{ft}$. In this report, the mathematically reduced form, foot squared per day $\left(\mathrm{ft}^{2} / \mathrm{d}\right.$ ), is used for convenience. To covert to $\mathrm{m}^{2} / \mathrm{d}$, multiply $\mathrm{ft}^{2} / \mathrm{d}$ by 0.0929 .

Sea level: In this report, "sea level" refers to the National Geodetic Vertical Datum of 1929-a geodetic datum derived from a general adjustment of the first-order level nets of the United States and Canada, formerly called Sea Level Datum of 1929. 
